\title{
Pineal Parenchyma
}

National Cancer Institute

\section{Source}

National Cancer Institute. Pineal Parenchyma. NCI Thesaurus. Code C41834.

The tissue of the pineal gland. The pineal gland is a small reddish-gray body, about $8 \mathrm{~mm}$. in length which lies in the depression between the superior colliculi. It is attached to the roof of the third ventricle near its junction with the mid-brain. It develops as an outgrowth from the third ventricle of the brain. The pineal parenchyma consists of follicles lined by epithelium and enveloped by connective tissues. It produces and secretes melatonin. 